IRENA WODZIANOWSKA* - LUBLIN

\title{
DOKUMENTACJA WIZYTACJI GRECKOKATOLICKICH W ARCHIWUM OBWODOWYM W ŻYTOMIERZU
}

Państwowe Archiwum Obwodowe w Żytomierzu powstało w 1920 r., gdy w celu wyjawienia i gromadzenia zbiorów likwidowanych przez władzę radziecką instytucji i organizacji na Wołyniu powołano Wołyńską Gubernialną Komisję Archiwalną. W 1922 roku Komisja została zlikwidowana, a w jej miejsce utworzono Wołyński Gubernialny Zarząd Archiwalny. Przez dziesięciolecia zmieniając nazwy, siedziby i sposób podporządkowania organom centralnym, instytucja ta od 1980 roku istnieje niezmiennie już jako Archiwum Obwodu Żytomierskiego. Jest ono jednym z najzasobniejszych archiwów obwodowych na Ukrainie gdy chodzi zarówno o liczbę przechowywanych materiałów jak i o zasięg terytorialny. Znajdujące się tu zbiory reprezentują głównie Wołyń, ale też Podole i Kijowszczyznę. Część dokumentów dotyczy również terytorium dzisiejszej Mołdawii, Białorusi czy Polski ${ }^{1}$.

Materiały podzielone są chronologicznie na zespoły: dorewolucyjny ${ }^{2}$, czyli obejmujący okres umownie do 1917 r. (część dokumentów z lat 20. XX w.) i porewolucyjny, które mieszczą się także w różnych budynkach. Zbiory zgrupowane są w 9277 zespołach, 1431302 j.a. ${ }^{3}$ Zgromadzono tu akta od wieku XVI po wiek XXI, chociaż zasadniczy zrąb pochodzi z lat 1795-1991.

* Irena Wodzianowska - dr historii, adiunkt w Instytucie Historii KUL.

${ }^{1}$ Архівні установи України. Довідник, Т. 1. Державні архіви, ред. кол. Г. В. Боряк, І. Б. Матяш, Г. В. Папакін, Київ 2005, s. 251; Архівні установи Украӥни. Довідник, ред. кол. О.С. Онищенко, Р.Я. Пиріг, Л.А. Дубровіна та ін., Київ 2000, s. 66-70.

${ }^{2}$ Zaznaczony literą „F”. Porewolucyjny jest skatalogowany w dwóch grupach: właściwy porewolucyjny (zaznaczony literką ,R” z lat 1930-2008) oraz archiwum Partyjne Żytomierskiego Komitetu Wykonawczego Komunistycznej Partii Ukrainy (litera „P”, z lat 1903-1991).

3 Zob. informacje liczbowe na stronie Państwowego Archiwum Obwodu Żytomierskiego: http://www.archive.zt.ua stan z 28 IX 2011 r. Historię tego archiwum przedstawia praca: P. Кондратюк, Державний архів Житомирської області. Історико-краєзнавчий нарис, Житомир 1997. 
Żytomierz miał już stosunkowo długą tradycję gromadzenia zbiorów, i przodowały tu instytucje religijne. Przede wszystkim aktywnie działało Wołyńskie Cerkiewno-Archeologiczne Towarzystwo, zrzeszające badaczy dziejów Cerkwi Prawosławnej na Wołyniu. Dzięki ich staraniom zachowała się część zbiorów bazyliańskich bibliotek, archiwów, a także wizytacji unickich. W 1893 roku z inicjatywy bpa Modesta oraz wspomnianego towarzystwa utworzono eparchialne archiwum, noszące nazwę Muzeum Cerkiewno-historycznych Pamiątek Wołynia. Zbiory obu instytucji miały na celu udokumentować obecność prawosławia na tych ziemiach, pomimo „naleciałości katolickich” 4.

Po 1905 r. powstało w Żytomierzu także katolickie muzeum diecezjalne, którego założycielem był bp A. K. Niedziałkowski. Prywatni kolekcjonerzy, jak chociażby hrabiowie Szoduarowie czy Platerowie posiadali w swych majątkach również liczne zbiory.

Wszystkie te czynniki złożyły się na fakt, że po procesie nacjonalizacji w okresie radzieckim zgromadzono w archiwum państwowym i ilościowo i jakościowo niezwykle ciekawy materiał. Te bezcenne zbiory żytomierskie ucierpiały w zasadzie kilkakrotnie - na skutek zawieruchy rewolucyjnej i wojny domowej (w okresie najaktywniejszej walki z religią) oraz działań wojennych I (ewakuowano zbiory archiwum prawosławnego do Charkowa) i II wojny światowej.

Zbiory zostały przetransportowane do Charkowa, jednak w drodze zbombardowano pociąg (1941). Ocalałe materiały uległy rozproszeniu - część zbioru pozostała w Charkowie, a część jeszcze przed wojną została wywieziona i włączona do zbiorów kijowskich.

Dokumenty do Żytomierza powróciły w zasadzie w stanie rozsypu, więc na nowo opracowywano katalogi i inwentarze. „Inwentarze archiwalne, opracowane najczęściej w latach 40.-60. XX w., nie posiadają indeksów osobowych i geograficznych. Istnieją natomiast katalogi do całości zasobu archiwum - tematyczny, imienny, geograficzny. Inwentarze sporządzone są w języku rosyjskim, najczęściej pismem odręcznym, nie zawsze czytelnym"`. Wykształconych archiwistów brakowało, więc powstały liczne nieścisłości. Dotyczą one zarówno nie poprawnego odczytania nazw geograficznych jak i niekonsekwentnego zapisu nazwisk $\mathrm{i}$ imion. Ponadto $\mathrm{w}$ inwentarzach określa się niektóre poszyty jako np. dokumenty w języku polskim; dokumenty po łacinie. Tytuły te z oczywistych względów nie ujawniają ich zawartości. Nie podaje się istotnych informacji np. przy klasztorach katolickich do jakiego zakonu należały, czy rozróżnienia pomiędzy parafiami łacińskimi a grecko-katolickimi. Niedbałe zapisy poszytów nie w pełni lub mylnie odzwierciedlają treść dokumentów. Przykładowo przy wizytacjach unickich, w tytule widnieje zapis wizytacji 6 dekanatów, a rzeczywistości jest tylko jeden dekanat ${ }^{6}$ lub zapis o wizytacji konkretnej parafii - a w rzeczywistości dekanatu

${ }^{4}$ С. Міщук, Палеографо-кодикологічний та бібліографічний опис рукописних книг та стародруків Волинського єпархіального давньосховища (1892-1919), w: Спеціальні історичні дисиипліни: питання, теорія та методики. 3б.наукових праць, т. 15, Київ 2007, s. 327.

${ }^{5}$ A. Nowak, Polonika $w$ archiwach obwodowych $w$ Żytomierzu i Chmielnickim (Ukraina), Miscellanea Historico-Archivistica, t. XV-XVI (2008-2009), Warszawa 2010, s. 218.

${ }^{6}$ Державний архів Житомирської області (dalej DAŻO), f. 178, op. 53, spr. 8. 
lub przynajmniej kilku parafii ${ }^{7}$. Gdyby zawierzyć inwentarzom - to się okaże, że w zasobach archiwum są również wizytacje z terenów Lubelszczyzny.

Dość niezrozumiałym jest mylne datowanie poszczególnych poszytów w przypadku dobrze zachowanych wizytacji ${ }^{8}$. Konkludując, w zasadzie zdarza się że mamy w teczce inne dokumenty, niż te które wynikały by z opisu w inwentarzu, jednak zaznaczyć należy, że prowadzone są uzupełniania katalogów i inwentarzy oraz opracowywanie nowych, bardziej szczegółowych.

W związku z tym nie znajdziemy w dwóch zachowanych zespołach unickich ${ }^{9}$ (z. 93 - Lubarski bazyliański klasztor, z. 420 - Litewski greckokatolicki duchowny konsystorz ${ }^{10}$ dokumentacji wizytacyjnej, pomimo że w zasobach archiwum żytomierskiego znajduje się jedna z najbogatszych kolekcji wizytacji unickich na Ukrainie. Są one włączone do czterech zespołów:

- z. 1 - Wołyński prawosławny konsystorz duchowny, w którym znajduje się około 400 protokołów wizytacyjnych z lat 1791-1792 ${ }^{11}$;

— z. 90 - Wizytator klasztorów diecezji łucko-żytomierskiej, gdzie w masie protokołów wizytacyjnych zarówno klasztorów i parafii łacińskich, jest kilka bazyliańskich monasterów oraz włączono dwie parafie greckokatolickie z dekanatu dubieńskiego;

— z. 569 - Kościół katolicki w Czudnowie, wśród metryk i papierów parafii zachowały się wizytacje dekanatów czudnowskiego i żytomierskiego z lat 17841785;

— z. 178 - Łucko-żytomierski konsystorz. W inwentarzu numer 53 tego zespołu znajduje się 50 poszytów wizytacji, w tym najstarszy z lat 1717-1732. Nie brakuje tu również dokumentów dotyczących Kościoła greckokatolickiego, ksiąg sądowych, metryk parafii greckokatolickich ${ }^{12}$.

W archiwum na dzień dzisiejszy zostały odnalezione raporty wizytacyjne 48 dekanatów, obejmujących geograficznie teren obwodu Chmielnickiego, Winnickiego, Kijowskiego, Czerkaskiego, Żytomierskiego, Równieńskiego, Tarnopol-

${ }^{7}$ Tamże, spr. 5.

${ }^{8}$ DAŻO, f. 178, op. 53 - przykładowo - spr. 3 (1782 zamiast 1717); spr. 6 (1759 zamiast 1742), spr. 7 (1783 zamiast 1746).

9 Державний архів Житомирської області. Анотований реєстр описів. Фонди дорадянського періоду, ред. кол. І. О. Рафальский, В. В. Будішевська, О. Г. Бовсунівська, Р. Ю. Кондратюк і інш., Житомир 2009, s. 55, 103.

${ }^{10}$ Oba zespoły zresztą są szczątkowe (7 j.a. i 49 j.a.), w pierwszym ze względu na specyfikę klasztor - wizytacji nie znajdziemy (lata 1790, 1833, 1836, 1838, 1840-1841, 1848) chociaż nie brakuje tu dokumentów dotyczących dominikańskiego klasztoru w tejże miejscowości oraz funkcjonowania parafii. Natomiast w drugim - księgi metrykalne z lat 1825, 1827-1836 oraz listy zakonników kilku klasztorów bazyliańskich.

${ }^{11}$ Protokoły te znajdujące się wśród dokumentów Zasławskiego duchownego zarządu prawosławnego. Por.: Р. Ю. Кондратюк, Джерела з історії Уніатської иеркви Південно-Східної Волині другої половини XVIII cm., „Архіви України” nr 4-5 (2001), http://www.archives.gov.ua/ Publicat/AU/2001-4-5-5.php

${ }^{12}$ Por. M. Radwan, Archiwa diecezji tucko-żytomierskiej. Repertorium, Lublin 2003. 
skiego, Odeskiego współczesnej Ukrainy, Białorusi ${ }^{13}$ i lewobrzeżnej części Mołdawii ${ }^{14}$. Najliczniejsze obejmują dekanaty - jampolski, komargrodzki i kraśniański (3-5). Są to zarówno wizytacje dziekańskie jak i generalne zarządzane przez biskupów A. Szeptyckiego, M. Ryłłę, S. Rudnickiego, J. Smogorzewskiego, T. Rostockiego jak i pełne tak szczątkowe na przestrzeni 50 lat (zob. tabela 1.).

Tabela 1. Wizytacje greckokatolickie odnalezione w archiwum

\begin{tabular}{|c|c|c|c|c|c|c|}
\hline \multirow{2}{*}{ Dekanaty } & \multicolumn{6}{|c|}{ Wizytacje $\mathrm{z}$ lat } \\
\hline & 1740-1749 & $1750-1759$ & 1760- 1769 & $1770-1779$ & 1780-1789 & 1790-1814 \\
\hline 1 & 2 & 3 & 4 & 5 & 6 & 7 \\
\hline Barasze & - & - & - & - & $\begin{array}{c}178-53-43 \\
(\mathrm{p})^{1}\end{array}$ & - \\
\hline Bazalia & - & $\begin{array}{c}178-53-17 \\
\text { (p) }\end{array}$ & - & - & - & - \\
\hline Berezna & - & - & - & - & - & $1-2-243(p)$ \\
\hline Berszada & - & - & - & - & $\begin{array}{c}178-53-36 \\
\text { (p) }\end{array}$ & - \\
\hline $\begin{array}{c}\text { Biała } \\
\text { Cerkiew }\end{array}$ & $\begin{array}{c}178-53-4 \\
(\mathrm{p}) \\
178-53-9 \\
(\mathrm{cz}) \\
178-53-10 \\
(\mathrm{cz})\end{array}$ & - & - & - & - & $\begin{array}{c}178-53-60 \\
(\mathrm{cz}) \\
178-53-63 \\
(\mathrm{cz}) \\
178-53-66 \\
(\mathrm{cz})\end{array}$ \\
\hline Bohusław & $\begin{array}{c}178-53-4 \\
\text { (p) }\end{array}$ & - & - & - & $\begin{array}{c}178-53-7 \\
(\mathrm{cz})\end{array}$ & - \\
\hline Bracław & - & - & $\begin{array}{c}178-53-25 \\
(\mathrm{p})\end{array}$ & - & $\begin{array}{c}178-53-41 \\
(\mathrm{cz}) \\
178-53-47 \\
(\mathrm{p})\end{array}$ & - \\
\hline Chodorków & - & - & - & - & $\begin{array}{c}178-53-33 \\
(\mathrm{cz})\end{array}$ & \\
\hline Czeczelnik & $\begin{array}{c}178-53-12 \\
\text { (p) }\end{array}$ & - & - & - & $\begin{array}{c}178-53-36 \\
\text { (p) }\end{array}$ & - \\
\hline Czehryń & $\begin{array}{c}178-53-4 \\
\text { (p) }\end{array}$ & - & - & - & - & - \\
\hline Czołhanie & - & $\begin{array}{c}178-53-17 \\
\text { (cz) }\end{array}$ & - & - & - & - \\
\hline Czudnów & - & - & - & - & $569-1-3 a(p)$ & - \\
\hline Dubno & - & - & - & - & $\begin{array}{c}90-1-336 \\
(\mathrm{cz})\end{array}$ & - \\
\hline Fastów & - & - & $\begin{array}{c}178-53-26 \\
(\mathrm{cz})\end{array}$ & - & - & $\begin{array}{c}178-53-62 \\
(\mathrm{cz})\end{array}$ \\
\hline
\end{tabular}

${ }^{13}$ Najstarsze z zachowanych - wizytacje Słucka z lat 1717-1732 oraz Rzeczyca z 1792. DAŻO, f. 178 , op. 53 , spr. 2 ; f. 90 , op. 1 , spr. 838 .

${ }^{14}$ Dekanat raszkowski z lat 1783-1784. DAŻO, f. 178, op. 53, spr. 2. 


\begin{tabular}{|c|c|c|c|c|c|c|}
\hline 1 & 2 & 3 & 4 & 5 & 6 & 7 \\
\hline Granów & - & - & $\begin{array}{c}\text { 178-53-23 } \\
\text { (p) }\end{array}$ & - & - & - \\
\hline Horyńgród & - & - & - & - & - & $1-2-243(p)$ \\
\hline Hoszcza & - & - & - & - & - & $1-2-243(p)$ \\
\hline Jampol & $\begin{array}{c}178-53-5 \\
\text { (p) }\end{array}$ & $\begin{array}{c}178-53-19 \\
(\mathrm{cz})\end{array}$ & & $\begin{array}{c}178-53-29 \\
(\mathrm{cz})\end{array}$ & $\begin{array}{c}178-53-2 \\
\text { (p) }\end{array}$ & - \\
\hline Jaruda & - & - & - & - & $\begin{array}{c}178-53-37 \\
\text { (p) }\end{array}$ & - \\
\hline Józefgród & - & - & - & - & $\begin{array}{c}178-53-36 \\
\text { (p) }\end{array}$ & - \\
\hline Kalnik & - & $\begin{array}{c}178-53-20 \\
\text { (p) }\end{array}$ & - & - & $\begin{array}{c}178-53-38 \\
\text { (p) }\end{array}$ & - \\
\hline $\begin{array}{l}\text { Kamieniec } \\
\text { Podolski }\end{array}$ & - & - & - & - & - & $\begin{array}{c}178-53-52 \\
(\mathrm{cz})\end{array}$ \\
\hline Kaniów & $\begin{array}{c}178-53-4 \\
\text { (p) }\end{array}$ & $\begin{array}{c}178-53-6 \\
(\mathrm{p}) \\
178-53-21 \\
(\mathrm{cz})\end{array}$ & - & - & - & - \\
\hline Klewań & - & - & - & - & - & $1-2-243(p)$ \\
\hline Komargród & - & - & $\begin{array}{c}178-53-24 \\
\text { (p) }\end{array}$ & $\begin{array}{c}178-53-29 \\
(\mathrm{cz})\end{array}$ & $\begin{array}{c}178-53-37 \\
(\mathrm{p}) \\
178-53-53 \\
(\mathrm{cz})\end{array}$ & - \\
\hline Korsuń & $\begin{array}{c}178-53-4 \\
\text { (p) }\end{array}$ & - & - & - & - & - \\
\hline Korzec & - & - & - & - & - & $1-2-243(p)$ \\
\hline Krasiłów & - & $\begin{array}{c}178-53-19 \\
(\mathrm{p})\end{array}$ & - & - & - & - \\
\hline Kraśne & - & - & - & $\begin{array}{c}178-53-29 \\
(\mathrm{cz})\end{array}$ & $\begin{array}{c}178-53-42 \\
(\mathrm{cz}) \\
178-53-48 \\
(\mathrm{cz}) \\
178-53-49 \\
(\mathrm{cz})\end{array}$ & $\begin{array}{c}178-53-50 \\
(\mathrm{cz}) \\
178-53-55 \\
(\mathrm{cz}) \\
178-53-59 \\
(\mathrm{cz})\end{array}$ \\
\hline Łabuń & - & $\begin{array}{c}178-53-16 \\
(\mathrm{p})\end{array}$ & - & - & - & $1-2-243(\mathrm{p})$ \\
\hline Moszna & $\begin{array}{c}178-53-4 \\
\text { (p) } \\
178-53-115 \\
(\mathrm{cz})\end{array}$ & - & - & - & - & - \\
\hline Niemirów & - & - & - & - & $\begin{array}{c}178-53-38 \\
\text { (p) }\end{array}$ & - \\
\hline Ostropol & - & - & - & - & - & $1-2-243(p)$ \\
\hline Owrucz & - & - & - & - & $\begin{array}{c}178-53-43 \\
\text { (p) }\end{array}$ & - \\
\hline
\end{tabular}




\begin{tabular}{|c|c|c|c|c|c|c|}
\hline 1 & 2 & 3 & 4 & 5 & 6 & 7 \\
\hline Ożohowiec & - & $\begin{array}{c}178-53-19 \\
(\mathrm{p})\end{array}$ & - & - & - & $1-2-243(p)$ \\
\hline Pawołocz & $\begin{array}{c}178-53-4 \\
\text { (p) }\end{array}$ & - & - & - & - & $\begin{array}{c}178-53-70 \\
(\mathrm{cz})\end{array}$ \\
\hline $\begin{array}{l}\text { Pohrebysz- } \\
\text { cze }\end{array}$ & $\begin{array}{c}178-53-4 \\
\text { (p) }\end{array}$ & - & - & - & - & - \\
\hline Połonne & - & - & - & - & - & $1-2-243(p)$ \\
\hline Przyłuka & - & $\begin{array}{c}178-53-15 \\
(\mathrm{cz})\end{array}$ & - & - & - & $\begin{array}{c}178-53-61 \\
(\mathrm{p}) \\
178-53-65 \\
(\mathrm{cz})\end{array}$ \\
\hline Raszków & - & - & - & - & $\begin{array}{c}178-53-2 \\
(\mathrm{p})\end{array}$ & - \\
\hline Stepań & - & - & - & - & - & $1-2-243(\mathrm{p})$ \\
\hline Śmiła & $\begin{array}{c}178-53-4 \\
(\mathrm{p}) \\
178-53-8 \\
(\mathrm{p})\end{array}$ & - & - & - & - & - \\
\hline Teofilpol & - & - & - & - & - & $1-2-243(p)$ \\
\hline Tetyjów & $\begin{array}{c}178-53-4 \\
\text { (p) }\end{array}$ & - & - & - & - & - \\
\hline Winnica & - & - & - & - & - & $\begin{array}{c}178-53-61 \\
(\mathrm{p})\end{array}$ \\
\hline $\begin{array}{l}\text { Woronowi- } \\
\text { ca }\end{array}$ & - & - & - & - & $\begin{array}{c}178-53-47 \\
(\mathrm{p})\end{array}$ & $\begin{array}{c}178-53-61 \\
(\mathrm{p})\end{array}$ \\
\hline Zasław & - & - & - & - & - & $1-2-243(p)$ \\
\hline Żytomierz & - & - & - & - & $569-1-3 a(p)$ & $\begin{array}{c}90-1-281 \\
(\mathrm{cz})^{2}\end{array}$ \\
\hline
\end{tabular}

${ }^{1}$ Wersja pełna wizytacji (80-100\% zachowanych opisów parafii) zaznaczona jest w tabeli literą - p, z kolei wersja szczątkowa lub zawierająca opis jednej lub kilka parafii ma oznaczenie - cz (część).

${ }^{2}$ Wizytacje te pochodzą z 1814 roku.

Zachowane tu wizytacje greckokatolickie ziem wschodnich Rzeczypospolitej można podzielić na kilka grup, według przyjętych kryteriów:

- ze względu na wizytatora - dziekańskie lub kanoniczne biskupów;

- okres czasowy - 1717-1814, chociaż gros raportów wizytacyjnych pochodzi z lat 1740-1792;

— stan zachowania - pełne - czyli zawierające opisy $80-100 \%$ terytorium dekanatu lub częściowe - zawierające ekstrakty, czyli wypisy z protokołów wizy- 
tacji, które pozostawały w parafiach po odbytej rewizji lub niepełne zachowane wizytacje dziekańskie lub biskupie ${ }^{15}$.

Liczba parafii w dekanatach wahała się w różnym okresie od 20 do 80 . Wszystkie odnalezione na dzień dzisiejszy wizytacje obejmują ponad 2000 parafii. Trzeba także zaznaczyć że część zbiorów jest w złym stanie technicznym i jest trudna do odczytania poprzez zniszczone karty jak np. w krasiłowskim dekanacie ${ }^{16}$.

Wizytacje biskupie w Kościele greckokatolickim mają długą tradycję, choć do początku XVIII wieku odbywały się nie często i nie wiele zachowało się ich do dnia dzisiejszego. Nie miały żadnych podstaw kanonicznych, normatywnych aktów czy wyznaczonego porządku i praw wizytatorów ${ }^{17}$. Sytuację zmienił synod zamojski, który odbył się w 1720 r. Postanowienia synodu składały się z 19 artykułów i objęły prawie wszystkie aspekty życia kościelnego. Zwrócono znaczną uwagę na reformę organizacji cerkiewnej i określenia praw i obowiązków duchowieństwa. Synod w art. 4 „O biskupach” postanawia, że do jego osobistych obowiązków należy wizytacja diecezji, by lepiej poznać powierzoną mu pastwę. Synod systematyzował praktykę wizytacji i zobowiązał biskupów by co rok lub co dwa lata rewidowali cały teren swojej diecezji. Zalegalizowano funkcjonującą w kijowskiej metropolii praktykę wyznaczania wizytatorów. Określono także, że rewizji podlegają wszystkie świątynie na terenie diecezji oraz bractwa, kolegia, szpitale. W trakcie wizyt należało zwracać uwagę na stan budynków, wyposażenie cerkwi oraz majątek. Zalecano szczególną troskę o stan moralny parafian, ich nauczania i przepowiadania Słowa Bożego.

By usprawnić pracę wizytatorów, na synodzie wypracowano listę pytań wzorowaną na łacińskim formularzu, jakie powinni zadać w czasie wizyty. Zaznaczono jednak, że te pytania w zależności od sytuacji można zmieniać i rozszerzać ${ }^{18}$. Zobowiązano wizytatorów do sporządzania protokołów, które powinni być zachowane w diecezjalnym i parafialnym archiwum.

Synod także regulował proces odbywania wizyt, maksymalnie skracając czas pobytu w parafii, oraz zakazując przyjmowania jakichkolwiek prezentów. W art. 9, dotyczących dziekanów, zaleca się by przeprowadzali oni wizytacje swoich dekanatów rok po generalnej wizytacji, by prześledzić wykonanie postanowień generalnej wizyty.

${ }^{15}$ Odnalezione są fragmenty większej całości czyli wizytacji kanonicznej J. Smogorzewskiego z 1783 roku dekanatu kraśniańskiego. Protokoły tej wizytacji zostały zidentyfikowane w trzech poszytach. W Żytomierzu zachowały się w sumie 11 parafii, prawdopodobnie kolejne 12 opisów tej wizytacji przechowywane są w Centralnym Państwowym Archiwum Historycznym Ukrainy w Kijowie (f. 972, op. 1, spr. 268).

${ }^{16}$ DAŻO, f. 178, op. 53, spr. 19.

${ }^{17}$ І. Скочиляс, Генеральні візитації в украӥнсько-білоруських єпархіях Київської уніатської митрополії. 1596-1720 роки, „Записки Наукового товариства імені Шевченка. Праці Історично-філософської секції”, т. СCXXXVIII, Львів 1999, s. 50-54.

${ }^{18}$ Przykłady instrukcji z późniejszego okresu zob.: Greckokatolickie dekanaty błoński i puchowicki w latach 1783-1784, wstęp i opr. I. Wodzianowska, Sandomierz 2006, s. 18-26; Wizytacje generalne parafii unickich $w$ województwie kijowskim i bractawskim po 1782 roku, opr. i wyd. M. Radwan, Lublin 2004, s. 26. 
Praktyka prowadzenia wizytacji zarówno przez biskupów jak i dziekanów była inna. Na rozległym terytorium metropolii kijowskiej nie udało się przeprowadzić wizytacji generalnej w ciągu jednego roku. Stawały temu na przeszkodzie zazwyczaj odległości pomiędzy parafiami, zły stan dróg, wydarzenia polityczne oraz obowiązki dziekanów, którzy pełnili funkcje proboszczów oraz byli gospodarzami we własnych majątkach.

Z najstarszych zachowanych $\mathrm{w}$ archiwum żytomierskim protokołów wizytacyjnych znajdujemy materiały dwóch zarządzonych przez arcybiskupa Atanazego Szeptyckiego. Pierwsza pochodzi w lat 1740-1741 i obejmuje 10 dekanatów Biała Cerkiew (67 parafii), Bohusław (20), Czehryń (27), Kaniów (36), Korsuń (38), Moszna (31), Pawołocz (40), Pohrebyszcze (39 parafii, ale brakuje kilku stron wizytacji), Smiła (26), Tetyjów (31) ${ }^{19}$. Wizytatorzy odnotowywali podstawowe informacje - nazwa miejscowości, wezwanie cerkwi, zaznaczali czy była drewniana lub murowana oraz rok jej powstania. Zapisywano także imię i nazwisko parocha, rzadziej biskupa, który udzielał świeceń kapłańskich lub roku tychże. Czasami wizytator podawał liczbę domów w parafii lub liczbę parafian oraz informacje o płaconej lub nie rokowszczyźnię dla kapłana.

Delegaci jednak nie zawsze mogli dokończyć objazdu dekanatów najczęściej $\mathrm{z}$ tego powodu, że ,[w Stawiszczach] haydamacy pokazali się y po innych wielu miejscach w tym dekanacie" ${ }^{20}$. W związku z tym w dekanacie białocerkiewskim zrewidowano tylko 48 z 67 parafii. W kaniowskim wizytatorzy także po wizycie 27 parafii odnotowali, że nie dokończyli „,z racyi że w Trachtamirowie pokazali się haydamacy y tak sami doiechac nie moglismy"21. Jednak na początku następnego, 1741 roku, delegowani kapłani powrócili i dokończyli objazd 9 pozostałych parochii.

W latach 1746-1747 A. Szeptycki ponownie zarządził wizytacje wszystkich dekanatów ukraińskich, czyli m.in. fastowskiego, pawołockiego, pohrebyskiego, białocerkiewskiego, kaniowskiego, moszyńskiego i in. W archiwum przechowywane są protokoły wyłącznie śmilańskiego z okresu 11 XI 1746-6 II 1747 r., czyli wizytacji zakończonej już po śmierci arcybiskupa ${ }^{22}$.

Kolejna grupa wizytacji biskupich pochodzi z 1756 r., a zarządzona została przez ordynariusza łucko-ostrogskiego Sylwestra Lubienieckiego Rudnickiego. Zachowały się raporty sześciu dekanatów: Bazalia (35 parafii), Czołhanie (19 parafii, tekst urywa się), Jampol (30), Krasiłów (31), Łabuń (34), Ożohowiec [St. Konstantynów] (36) ${ }^{23}$.

${ }^{19}$ Jest to najliczniejszy poszyt zawierający 447 kart. DAŻO, f. 178, op. 53, spr. 4.

${ }^{20}$ DAŻO, f. 178 , op. 53, spr. 4, k. 68 v.

${ }^{21}$ DAŻO, f. 178, op. 53, spr. 4, k. 130. Rozpoczęli wizytacje dziekan żytomierski Jan Gledkiewicz i oficjał G. Kozubski, a dokończyli dziekani - pawołocki Teodor Bielawski i kaniowski Bazyli Andryjewski. Podobnie dokończyli oni rewizji także dekanatu moszeńskiego (14 parafii) w styczniu 1741 r. A ci sami kapłani wizytowali też dekanat korsuński, czehryński, bohusławski, śmilański i tetyjowski.

${ }^{22}$ DAŻO, f. 178 , op. 53 , spr. 8.

${ }^{23}$ DAŻO, f. 178 , op. 53, spr. 16, 17, 19. 
W tych raportach została zmieniona instrukcja wizytacji. Oprócz podstawowych informacji - miejscowość, wezwanie, nazwisko duchownego, dołączono informacje o antymisie, wystroju i uposażeniu cerkwi (np. alby, obrazy, księgi); podawano opis cmentarza i dzwonnicy; opisano ilość nadań funduszowych - ziemi ornej, łąk, folwarków, ogrodów, lasów, stawów, sadów, pasiek; ograniczone informacje o kolatorach; bractwie i jego finansach ${ }^{24}$; zaznaczano istnienie rezydencji kapłańskiej. Zawierały one także podstawowe informacje o wiernych liczba domów, przysiółków należących do parochii ${ }^{25}$ oraz „dusz partycipuiących S Sakramenta"26.

Tempo przeprowadzania wizytacji jest dość szybkie, zgodnie z postanowieniami synodu zamojskiego, wizytatorzy pozostawali w parafiach tylko jeden dzień. Objazd dekanatów zajmował delegatom tylko dwa miesiące, przykładowo bazalijskiego - styczeń-luty, jampolskiego - październik i grudzień 1756 r. Należy dodać, że przebiegały one dość sprawnie, gdyż ogólnie wizytowanie niektórych dekanatów przeciągało się nieraz i kilka lat. Zależało to od delegowanego wizytatora, który najczęściej przeprowadzał objazd 2 lub 3 dekanatów. Delegowanymi przez abpa Smogorzewskiego do przeprowadzenia wizytacji byli dziekani z innych terenów, m.in. owrucki Jan Modliszewski do czudnowskiego i żytomierskiego; brahiłowski Bazyli Rogala Lewicki do baraszowskiego i owruckiego; żytomierski Piotr Wagatowicz do bracławskiego i kraśniańskiego; tetyjowski Bazyli Stopczański do jampolskiego i raszkowskiego; włodarski Grzegorz Łapiński do kalnickiego i niemirowskiego; białocerkiewski M. Urbanowicz do czeczelnickiego, józefgródzkiego i berszadzkiego. Jednak prawie we wszystkich przypadkach, w okresie letnio-jesiennym urządzano przerwę. Czas przeprowadzenia wizytacji najlepiej jest widoczny na najbardziej reprezentatywnej grupie wizytacji z lat 1782-1785.

\begin{tabular}{|c|c|c|}
\hline Nazwa dekanatu & Okres trwania wizytacji & Liczba parafii \\
\hline 1 & 2 & 3 \\
\hline Barasze & $\begin{array}{c}19 \text { XII } 1783-29 \text { I } 1784 \\
27 \text { II }-15 \text { III } 1784\end{array}$ & 44 \\
\hline Bracław & $\begin{array}{l}17 \mathrm{III}-11 \mathrm{IV} 1785 \\
6 \mathrm{VI}-26 \mathrm{VI} 1785\end{array}$ & 41 \\
\hline Berszada & $\begin{array}{c}10 \text { I }-28 \text { II } 1784 \\
14 \text { X }-25 \text { XI } 1784\end{array}$ & 44 \\
\hline Czeczelnik & $\begin{array}{c}11 \text { XII } 1782 \text { - } 19 \text { III } 1783 \\
3-25 \text { III } 1784 \\
4-13 \text { X } 1784\end{array}$ & 41 \\
\hline
\end{tabular}

${ }^{24} \mathrm{~W}$ parafii Ożohowiec bractwo posiadało w skarbonie $30 \mathrm{zł} 20 \mathrm{gr}$, oraz 30 pni pasieki. DAŻO, f. 178 , op. 53 , spr. 19 , k. 2.

${ }^{25} \mathrm{~Np}$. w parafii Stroki było „152 gospodarzy wraz z wioskami Trojanowską, Zarudcem, Ledóchowką, Olejnikami”. DAŻO, f. 178, op. 53, spr. 17, k. 36 v.

${ }^{26}$ DAŻO, f. 178 , op. 53 , spr. 19, k. 7. 


\begin{tabular}{|c|c|c|}
\hline Czudnów & $\begin{array}{c}7 \text { II }-22 \text { II } 1785 \\
11 \text { III }-1 \text { IV } 1785 \\
22-23 \text { IV } 1785\end{array}$ & 40 \\
\hline Jampol & 1 III $1784-?$ & 42 \\
\hline Jaruda & $\begin{array}{c}27 \text { II }-8 \text { IV } 1783 \\
28 \mathrm{X}-20 \text { XII } 1783 \\
\end{array}$ & 41 \\
\hline Józefgród & 13 II $1783-?$ & 46 \\
\hline 1 & 2 & 3 \\
\hline Kalnik & $\begin{array}{c}27 \text { XI - } 14 \text { XII } 1782 \\
15 \text { I - 27 I } 1783 \\
5 \text { III - } 13 \text { III } 1785\end{array}$ & 42 \\
\hline Komargród & 28 XII 1783 - 30 I 1784 & 41 \\
\hline Niemirów & $\begin{array}{l}30 \text { I }-24 \text { II } 1783 \\
18 \text { I }-27 \text { I } 1785\end{array}$ & 43 \\
\hline Owrucz & $\begin{array}{c}23 \text { III }-5 \text { V } 1783 \\
1 \text { II }-5 \text { III } 1784 \\
\end{array}$ & 43 \\
\hline Raszków & $\begin{array}{c}27-29 \text { II, } 29 \text { III }-7 \text { IV } 1783 \\
15 \text { II }-18 \text { III } 1784\end{array}$ & 47 \\
\hline Woronowica & 17 I - 13 III 1785 & 42 \\
\hline Żytomierz & $\begin{array}{c}20 X-20 \text { XI } 1783 \\
23 \text { IV }-3 \text { V } 1784 \\
2 \text { IV }-21 \text { IV } 1785\end{array}$ & 44 \\
\hline
\end{tabular}

Jak można zauważyć, że najsprawniej przebiegała wizytacja w dekanacie komargrodzkim i woronowickim, średnio zajmowała ona wizytatorom około 2-3 miesięcy, a w przypadku kalnickiego, raszkowskiego i żytomierskiego dwa lata.

Podobna liczba protokołów wizytacyjnych została odnaleziona także z okresu Felicjana Wołodkowicza, koadiutora, a następnie metropolity kijowskiego. Są to dwie wizytacje - granowskiego z 1760 r. (52 parafie) i komargródzkiego z 1761 r. (55 parafii $)^{27} \mathrm{i}$ w zasadzie zakres informacji nie uległ zmianie.

W podobnym stylu ścisłego opisu przeprowadzone są wizytacje przez Maksymiliana Ryłło w $1773 \mathrm{r}^{28}$. Zachowany poszyt zawiera szczątkowe protokoły dekanatu jampolskiego (13, urwany tekst), komargrodskiego (6) oraz kraśniańskiego (1, urwany tekst poszytu).

Najciekawsze i najbardziej reprezentatywne dla tego terenu są wizytacje metropolity kijowskiego Jasona Smogorzewskiego z lat 1782-1785. Przechowywane w archiwum materiały obejmują 15 dekanatów z 48 wówczas istniejących w województwie bracławskim i kijowskim ${ }^{29}$ :

Barasze, Bracław ${ }^{30}$, Berszada, Czeczelnik, Czudnów ${ }^{31}$, Jampol, Jaruda, Józefgród, Kalnik, Komargród, Niemirów, Owrucz, Raszków, Woronowica, Żyto-

${ }^{27}$ DAŻO, f. 178 , op. 53, spr. 23-24.

${ }^{28}$ DAŻO, f. 178 , op. 53, spr. 29.

${ }^{29}$ Socjografia Kościoła greckokatolickiego na Bracławszczyźnie i Kijowszczyźnie w 1782 roku, opr. i wyd. M. Radwan, Lublin 2004, s. 15.

${ }^{30}$ Wydany drukiem: Wizytacje generalne parafii unickich, s. 439-666.

${ }^{31}$ Tamże, s. 249-437. 
mierz $^{32}$. Akurat te wizytacje są najbardziej znane za sprawą opracowania i wydania ich drukiem przez ks. prof. Mariana Radwana.

Wizytacje tworzą najpełniejszy obraz sytuacji w parafiach, obejmując właściwie wszystkie dziedziny życia ${ }^{33}$. Jest to również ciekawy materiał gdy chodzi o historie poszczególnych miejscowości. Pojawiają się wiadomości o powstaniu danej miejscowości, np. w Harabach wizytator zapisuje, że „osada niedawna” ${ }^{34}$. Biorąc pod uwagę, że najczęściej cerkiew budowano właściwie od razu po osiedleniu się ludzi, to miejscowość powstała po 1760 roku. Drewniana cerkiew pod wezwaniem Protekcji NMP bowiem została zbudowana w 1765 r. W protokołach wizytacyjnych pojawiają się informacje o najazdach tatarskich, spustoszeniach i pożarach. Przykładowo w dekanacie raszkowskim, gdzie na 47 parafii wizytatorzy odnotowują 28 spalonych cerkwi przez Tatarów tylko w 1769 r. Niezwykle trudno jest ustalić także powstanie parafii i założenia pierwszej świątyni, gdyż częste najazdy tatarskie i branie ludzi „,w plen” spowodowało, że w miejscowościach nie było osób starszych, które mogły cokolwiek pamiętać z przekazów.

Każda z wizytowanych miejscowości stanowiła samodzielną parafię, do której ewentualnie należały przysiółki. Gęstość zaludnienia większości wizytowanych parochii to ponad 200 do 500 osób (51-100 domów). W dekanatach bracławskim, kalnickim, komargródzkim i woronowickim stanowiły one połowę wszystkich działających. Najmniej parafii należało do grupy, w której liczba domów przekraczała 150-200 (czyli 1400-1600 mieszkańców), średnio 5-6 parafii w dekanacie. Wyjątkowo tylko na terenie dekanatu komargródzkiego tak gęsto zaludnionych wsi w ogóle nie było. Wizytatorzy odnotowują przy podaniu liczby domów w parafiach, że „reszta Mazurowie” (dekanaty bracławski i woronowicki), przestrzegają przed mieszanymi małżeństwami z Tatarami lub nakazują zwalnianie się ze służby u Żydów w niedziele i przychodzenie do cerkwi na mszę. Wiadomości te pozwalają także na odtworzenie składu narodowościowego miejscowości oraz relacji zachodzących między ludźmi ${ }^{35}$.

Gdy chodzi o relacje międzywyznaniowe, to pojawia się po raz pierwszy wyraźne rozróżnienie o uczęszczaniu osób z rodzin „ruskich” do cerkwi, a polskich do kościoła i zakaz chodzenia na przemian oraz ostrzeżenia przed mieszkającymi w pobliżu starowierami.

${ }^{32}$ Tamże, s. 29-247.

${ }^{33}$ Por.: I. Wodzianowska, Powizytacyjne raporty dekanatów greckokatolickich jako źródto historyczne, w: Шевченківська весна: матеріали міжнар. наук.-практ. конф. студ., асп. та молодих вчених, присвяч. 90-річчю з дня заснування Українського Студентського Наукового Товариства Київського Університету Св. Володимира. Історія: праці вчених, заг. ред. О.К. Закусило, Київ 2008, вип. 6, ч. 1, s. 227-230; taż, Уніятські парафії на Бращлавщині у другій половині XVIII століття, w: Історія релігій в Украӥні. Науковий щорічник, від. Ред. Т. Вишневська, Львів 2009, кн. 1, s. 262-269.

${ }^{34}$ DAŻO, f. 178 , op. 53, spr. 2, k. $113 \mathrm{v}$.

${ }^{35} \mathrm{Nie}$ zawsze są one pozytywne. W przypadku Żydów pojawiają się najczęściej zapisy, że „był zwyczaj kanonu sycenia, lecz przez zdzierstwo od Żydów upadł 2 lata temu”. DAŻO, f. 178, op. 53, spr. 47, k. 261 v. 
Daje się zauważyć dbałość o dostęp wiernych do cerkwi - bliskie odległości pomiędzy miejscowościami lub rozgraniczenie parafii tak, by wiosenne roztopy nie przeszkadzały w dotarciu do świątyni. Wizytatorzy nakazywali zadbanie o to, by ludność pracująca w miastach czy we dworach miała możliwość pójść na niedzielne nabożeństwo. W przygranicznych rejonach z Mołdawią wizytator ,po wołosku bez skazitelności jednak Pisma Sw., obowiązków zbawienia, uczyć temuż X. Parochowi przykazał" 36 miejscową ludność. W trakcie wizytacji pytał on parafian ,z katechizmu, gdy nie odpowiedzieli, justifikowali się iż po rusku nie umieią, a X.Paroch po rusku przepowiada, a po wołosku nauk nie miewa" ${ }^{37}$. Nakaz by miejscowi księża nauczyli się języka zamieszkałej tam ludności dotyczył przede wszystkim tych miejscowości, które zostały utworzone przez uciekinierów z imperium osmańskiego i osiadłych nad Dniestrem w dekanatach raszkowskim i jampolskim. Początkowo pracowali tam rekoncyliowani księża wołoscy, więc problemu nie było, natomiast pojawia się w drugiej połowie XVIII w., gdy ich liczba maleje.

Zwracano uwagę również na poziom religijny, na sytuację moralną parafian, częstotliwość przystępowania do sakramentów, szczególnie spowiedzi wielkanocnej. Wizytator egzaminował wiernych z podstawowych prawd wiary i umiejętności modlenia się ${ }^{38}$. Notował następnie w końcowym dekrecie wskazówki duszpasterskie dla parocha. Nawet, gdy wizytator stwierdzał dbałość kapłana o wiernych, w dekrecie powizytacyjnym i tak można przeczytać napomnienie o głoszeniu Słowa Bożego, uczeniu wiernych katechizmu czy pacierza. Równocześnie bardzo podkreśla się groźbę indyferentyzmu, będącą następstwem pracy najemnej w niedzielę oraz małżeństw mieszanych.

Odnotowywano kultywowanie pogańskich zwyczajów na terenie parafii czy wróżb. „A że parochianie dombrowinieccy obmierzły Bogu i ludziom zwyczay zachowują, obchodząc corocznie w lecie, w dzień świętego Jana bałwochwalskie obrzędy czyniąc, kupała i przy tym nocnych schadzek dozwalają młodzieży, aby odtąd takowych gustów i rozpusty nie bywało, pod odłączeniem od cerkwi i podaniem takowych wklątew zakazałem" ${ }^{39}$. Wszelkie związki pozamałżeńskie, niemoralne prowadzenie się, przemoc domowa, kradzieże, pijaństwo były sądzone lub rozstrzygane przez wizytatora. Gdy je nie zgłaszano, notowano, że „o występkach i iawnych grzechach w tey parochyi nie słychac"40.

Wizytator był zobowiązany zbadać sytuację bractw, sposób prowadzenia przez nich ksiąg oraz utrzymania cerkwi. Aktywność bractw przejawiająca się w remontowaniu, zaopatrywania w potrzebne sprzęty cerkiew itp. Ciekawym ele-

${ }^{36}$ DAŻO, f. 178 , op. 53, spr. 2, k. 24 v.

${ }^{37}$ Tamże.

${ }^{38}$ „Aże pod czas teyże wizyty po nauce pod czas katechizmach wielu z młodzieży sprzeciwiaiących się na pytania odpowiadać niechcących, na ostatek z cerkwi uciekaiących widziałem, więc dla poskromienia zuchwałości onych, aby WX paroch o to usilnie starał się żeby onych częscio głaskaniem, częscio boiaźnią do nauk zwykłych nakłaniać, artykułów wiary nauczać”. DAŻO, f. 178, op. 53, spr. 42 , k. 2 v.

${ }^{39}$ DAŻO, f. 178, op. 53, spr. 38, k. 32v.

${ }^{40}$ DAŻO, f. 178 , op. 53 , spr. 36, k. 334. 
mentem jest także zapis skarbony bractwa w różnych miejscowościach podawany w złotówkach, talarach czy rublach ${ }^{41}$. Bractwa były praktycznie przy każdej cerkwi, a w miastach istniały także cechy - tkacki, szewski, garncarski, kuśnierski, rzeźnicki, które ze swych skarbonek wspierały cerkiew, chociażby w oświetleniu jej. Przy niektórych parochiach funkcjonowały nieraz po dwa bractwa - starsze i młodsze. Niektórzy wizytatorzy wymieniają nie tylko liczbę, ale i z imienia i nazwiska wszystkich osób należących do bractwa. Każdorazowo zaznaczano, czy bractwo ma pasiekę, ile posiada pieniędzy, wosku. Na nich również spadał obowiązek dbania o remonty cerkwi.

Wizytator podawał znacznie więcej wiadomości o duchownych. Oprócz danych personalnych proboszczów i wikariuszy (ich wykształceniu, wieku, pochodzeniu) również nazwiska biskupów, którzy ich wyświęcili, a także kolatorów, przedstawiających do danego beneficjum. Pojawiają się informacje o rodzinach parochów - małżonkach i dzieciach ${ }^{42}$. Szczegółowe dane dotyczą przede wszystkim synów - liczba, wiek, wykształcenie, zajęcie, a informacji o córkach w rodzinach duchownego w ogóle brakuje. Niestety nie wszyscy wizytatorzy oprócz krótkiej charakterystyki kapłana ${ }^{43}$, odnotowywali wykształcenie ${ }^{44}$ lub wiek duchownego. W dekanacie bracławskim wizytator zaznaczył, czy duchowny „był w szkołach łacińskich” (przy 11 osobach) lub posiadał „edukację domową” (22), i tylko w jednym przypadku - „nieedukowany”. W komargrodzkim - kształconych w szkołach łacińskich było 13 parochów, ale nieedukowanych -9 .

Wizytatorzy notują także problemy duchownych, np. pijaństwo, kłótni z wiernymi, nadużycia dotyczące wysokości opłat za sprawowanie obrzędów ${ }^{45}$. W kilku dekanatach zaznaczają pochodzenie społeczne kapłanów. Pozwala to na dokona-

${ }^{41}$ Bractwa nie zawsze posiadały gotówkę, chociażby jak w dekanatach raszkowskim czy niemirowskim, gdyż wydały je na remonty czy odbudowy świątyń po spaleniu przez Tatarów.

${ }^{42}$ Zob. szerzej: I. Водзяновска, Сім'я уніятського священика на Бращлавщині у другій половині XVIII століття, w: Історія релігій в Украйні. Науковий Щорічник, кн. 1, Львів 2010, s. $254-261$.

${ }^{43}$ Przykładowo: „Paroch W.X Jan Samborski mający lat 43, poświęcony na prezbitery od JW. Felicjana Wołodkowicza w roku 1772 w Kupiczowie dnia 2 Junii prezentowany od JW Wincentego Potockiego wojewody kijowskiego w roku 1772 dnia 22 Augustii. Instytuowany od teraźniejszego JW. archipasterza Jasona Smogorzewskiego przez PW. Xiędza dziekana Szubowicza niemirowskiego w roku 1781 dnia 20 Septembris. Żona tegoż parocha $\mathrm{z}$ indagacji parochii okazała się bydz stateczną, synów nie ma”. DAŻO, f. 178, op. 53, spr. 38, k. 83.

${ }^{44}$ Zob. szerzej: P. Staniszewski, Unickie duchowieństwo w dekanacie bractawskim w świetle wizytacji z 1785 r., „Nasza Przeszłość”, 111 (2009), s. 5-54; I. Водзяновска, Освіта грекокатолицького духовенства на Бращлавщині в др.пол. XVIII cm. (на прикладі вороновииького деканату), w: Дні науки Історичного Факультету - 2010. Матеріали ІІІ Міжнародної наукової конферениіі молодих учених, присвяченої 65-річчю Перемоги у Великій Вітчизняній Війні, вип. III, ч. 1, Київ 2010, s. 13-15.

${ }^{45}$ Ustalone były tzw. przychody stuły, za które kapłani i diacy pobierali określone sumy. Wynosiły one od 3 groszy do 8 złotych. Obejmowały zapowiedzi ślubne, udzielenia sakramentów, msze św., pogrzeby, przeczytanie ewangelii nad zmarłym w domu, święcenie pokarmów. „Z modlitwą kapłan obchodzi domy razy 2 do roku, a trzeci z kropidłem, mieszczanie daią po gr. 3 i chlib, a drudzy chlib y co łaska za miastem mieszkaiący”. Por. DAŻO, f. 178, op. 53, spr. 2. 
nie już pewnych analiz, chociażby pochodzenia duchownych, wykształcenia, relacji rodzinnych, pracy duszpasterskiej, gospodarowania i sposobów oddziaływania. Zapisy takie jak - po swoim ojcu przejął parafie, po nim jego syn, przedtem był jego ojciec - pozwalają na ustalenie także pewnych zależności w zakresie obsadzania stanowisk duszpasterskich.

W protokołach wizytacyjnych zawsze było zaznaczane jeżeli wierni nie stawili się przed wizytatorem. Nie chodziło tylko o bractwo, które musiało przedstawić księgi rachunkowe do sprawdzenia, ale o zwykłych parafian. Każdorazowo znajdujemy zapis, że właśnie z relacji wiernych miejscowy paroch „okazał się być czułym, trzeźwym, nauki zawsze miewającym w teologii moralnej wydoskonalonym"46. I takie określenia padają najczęściej - stateczny, przykładny, czuły.

Podstawą utrzymania proboszcza były nadania funduszowe, których najważniejszymi elementami były ziemie orne i sianożęćc ${ }^{47}$. Najczęstsze nadania to obszar mierzony w 30, 45, 60 dniach orania - co stanowi 70\% wszystkich funduszy. Maksymalna ilość ziemi ornej to 120-126 dni orania (71-75 ha), spotyka się najrzadziej - po jednej parafii w dekanatach bracławskim i komargrodzkim, a najszczuplejsze w woronowickim ( $2 / 3$ wszystkich funduszy waha się od 9 do 24 ha ziemi uprawnej) oraz niemirowskim (od 8 do 36 ha). Gdy chodzi o sianożęć, to tu podobnie największe obszary - na 90, 100, 108 kosiarzy - po 1-2 parafii w dekanatach bracławskim, komargrodzkim, a najmniejsze w woronowickim oraz niemirowskim (w połowie parafii sianożęć wynosi mniej niż 20 kosiarzy). Ciekawe zapisy pojawiają się w dekanacie raszkowskim, że ksiądz ziemi „używa z ludźmi, gdyż grunta są rozległe" ${ }^{48}$, bez uwzględnienia ilości ziemi nadanej przez fundatora.

Ponadto $\mathrm{w}$ zapisach funduszowych figurują ogrody, sady, stawy ${ }^{49}$, place pod plebanie i budynki gospodarcze ${ }^{50}$ parocha oraz przywileje ${ }^{51}$, jak zwolnienie ze wszystkich robocizn i podatków pieniężnych na dwór lub gromadę, dziesięcin owczych, pszczelich, zbożnych i in. Burzliwe dzieje tych ziem spowodowały, że

${ }^{46}$ DAŻO, f. 178 , op. 53 , spr. 38 , k. 10

${ }^{47}$ Pierwsza liczona w dniach orania (równoważny 0,6 ha) lub pługach, i tylko w kilku przypadkach w sznurach; druga w liczbie kosiarzy potrzebnych do pracy.

${ }^{48} \mathrm{DAŻO}$, f. 178 , op. 53 , spr. 2, k. 91.

${ }^{49}$ Można prześledzić chociażby brak zapisów w postaci stawów w dekanatach, gdzie parafie leżą w pobliżu rzek, m.in. w raszkowskim - nad Dniestrem lub jego dopływami.

${ }^{50}$ „Dom plebalny, izba z alkierzem, sieńmi i piekarnią, przy którey i spiżarnia, szpichlerz, loch, szopy, stodoła, sadek etc.” DAŻO, f. 178, op. 53, spr. 38, k. 26 v.

${ }^{51}$ Przykładowo Konstantego Ludwika Platera z 1755 roku w funduszowym zapisie dla cerkwi Daszowskiej pw. Zaśnięcia NMP: [...] pozwalam przy tej cerkwi mieszkanie, ogrody, pola po dni dziesięć, sadów i wolność używania lasów na swoją tylko potrzebę, tudzież spokojnego zażywania dochodów i obwencji zwyczajnych kapłańskich z parafii do niego należącej ad vitae eius tempora bez żadnych dworskich i innych cuiuscumque tituli podatków pozwala się też na własną jego domową potrzebę, cztery spusty w rok gorzałki wykurzyć. Oprócz aktów to jest chrzcin i wesel waruje się, aby wódki nie szynkował i żadney prepedycyi arędarzom nie czynił. Piwa takoż warzenia na potrzeby onego wolne zachowuję. Uwalniam go też od dziesięciny pszczelney, od rogowszczyzny, czynszów, osypów, powozów i innych niebywałych przedtym ciężarów. Mliwo takoż bez czerhy pozwala się i sycenie miodu kanonnego na praznik raz w rok [...]”. DAŻO, f. 178, op. 53, spr. 38, k. $25-25 \mathrm{v}$. 
nie przy wszystkich parafiach zachowały się erekcje - najazdy tatarskie, pożary drewnianych świątyń, zmiana wyznania, thumaczone lakonicznymi zapisami „w rewolucje zginęła".

Gdy chodzi o fundatorów cerkwi i jej uposażenia, to mamy tutaj całą mozaikę - rody magnackie i szlacheckie, klasztory zarówno łacińskie jak i unickie oraz biskupi rzymskokatoliccy. W niektórych dekanatach zaznacza się przewaga poszczególnych rodów jak przykładowo w czeczelnickim - Potockich, w raszkowskim - Lubomirskich, kalnickim - Sanguszków i Platerów. Z pomniejszych fundatorów należy wymienić - Grocholskich, Zarzyckich, Urbanowskich oraz Kordyszów (po 4-8 parafii w dekanacie). W niektórych parafiach, jak chociażby w dekanacie woronowickim, jest po kilku kolatorów, np. w Witawie są to Zagórscy, Nosalscy, Wieliccy, Jagiełłowiczowie i in.

Zwracano uwagę także na relacje z dworem i kolatorami, gdyż niektóre zapisy świadczą, że paroch dworowi był dobrze znany. Jeżeli pojawiały się zatargi, to dotyczyły one jednostronnej rewindykacji zapisów funduszowych przodków i uszczuplenia gruntów. Problemem bywały także zaniedbania ze strony dworu dotyczące nakładów na remonty cerkwi.

Zapisane są również burzliwe dzieje tych ziem po 1768 roku oraz masowe „nawracanie" na prawosławie, które objęło wszystkie rewidowane dekanaty. „Cerkiew ta parchomowska w roku 1772 przez moc protopa Liniewicz z pomocą komendy rosyjskiej na dyzunię była wzięta, po tym zaś w roku 1776 miesiąca lutego dnia 3go, gromada z parochem w konsystorzu bracławskim rekoncyliowała się" 52 lub „Cerkiew ta w czasie inkursji odebrana była na dyzunię w roku 1773, rekoncyliowana została w roku 1779 "53. Wraz z parafiami zmieniali wyznanie również i ich duszpasterze. Wizytatorzy każdorazowo odnotowywali apostazje jak „WX Jan Błażewski wyordynowany na prezbitery od JW. Leona Szeptyckiego w roku 1772 miesiąca Augusto 15 dnia we Lwowie, w czasie prześladowania unii przymuszony od dyzunitów do apostazji. Od której absolwowany i dyspensowany przez wielmożnego jegomość Xa Lubińskiego oficjała bracławskiego w roku 1779 dnia 22 Octobris vs." ${ }^{54}$. Zwracano uwagę również na zamieszkanie we wsiach kapłanów trwających nadal w odstępstwie oraz na możliwe przeszkody w pracy duszpasterskiej proboszcza.

Każdy dokument wizytacyjny rozpoczynał bardzo szczegółowy opis architektury cerkwi. Ogromna większość świątyń na tym terenie była drewniana o trzech

\footnotetext{
${ }^{52}$ DAŻO, f. 178, op. 53, spr. 38, k. 19.

${ }^{53}$ Tamże, k. 67 v.

${ }^{54}$ Tamże.
} 
kopułach $^{55}$, ale zdarzały się także i ,na kształt kapliczki”" ${ }^{56}$. Następnie przedstawiano uposażenie cerkwi oraz księgi liturgiczne, ale także biblioteki prywatne kapłanów ${ }^{57}$. W dalszej kolejności następował opis terenu przycerkiewnego, w tym dzwonnicy i cmentarza, przy czym wizytator notował ilość dzwonów oraz czy cmentarz był ogrodzony.

$\mathrm{Na}$ terenie cerkiewnym znajdowała się zazwyczaj szkoła, w której miejscowy diak uczył dzieci czytać i pisać. Informacje zawarte w wizytacjach pozwalają na odtworzenie gęstości tychże szkół oraz ukazania ich liczebności oraz pochodzenia społecznego diaków. Rzadziej spotyka się zapisy dotyczących pałamarzy. Najczęściej przy parafiach pełnili tę funkcję członkowie bractw lub parafianie na zmianę. Natomiast jeśli już była specjalnie wynajmowana do tego osoba, to wizytator notował czy był on wolny ${ }^{58}$, jeżeli nie nakazywał bractwu wykupić go. Znajdujemy także opisy szpitali przy niektórych parafiach, które pełniły raczej rolę przytułków dla biednych i starszych osób ${ }^{59}$.

Wszystkie niedociągnięcia w parafii oraz pracy duszpasterskiej kapłana które zauważył wizytator, odnotowywał w dekrecie reformacyjnym. Kapłanów upominano najczęściej z powodów „ochędóstwa” w cerkwi czy pilnowania ksiąg brackich. Powtarza się nakaz dla kapłana by „w administrowaniu sakramętow S w daniu nauki Chrystusowey dla swoich parochia być czułym pastyrzem" ${ }^{60}$. Jeden z najczęstszych wymogów pod adresem proboszczów dotyczył prowadzenia ksiąg

${ }^{55}$ „Cerkiew parochialna jurkowiecka pod tytułem Uśpienia Matki Najświętszej w kollacji ad praesens JW. Platera pisarza polskiego Wielkiego Księstwa Litewskiego wystawiona a prima radice nikt nie zapamięta, restaurowana za konsensem JW. Leona Szeptyckiego przez wielmożnego Markowskiego oficjała barskiego na gruncie w Jurkowcach pod czas wizyty generalnej podpisanym w roku 1751 dnia 28 miesiąca Februari. [Cerkiew] o trzech wierzchach z kopułami gątą pobitymi, na których krzyżów żelaznych 3, tarcicami lipowemi oszalowana, z opasaniem gątą pobitym. Drzwi jedne na żelaznych zawiasach zamkiem wewnętrznym opatrzone. Podłoga dębowa, okien za gratami 5, a bez grat 3. Deisus snycerskiej roboty o zwyczajnych trzech wratach marcypanowo malowany, mensa z obchodem trzema obrusami, jednym prostym, a dwoma szwabskiemi pokryta, na której ołtarzyk z cymborią marcypanowo malowany. Sanctissimum w puszce srebrnej wyzłacanej na korporale czystym. Olea sacra w mirnicach cynowych. Antemis Jllmi Athanasii Szeptycki z relikwiami nienaruszonemi. Dzwonnica z komorą i kopułą gątą pobita. Cmentarz częstokołem ogrodzony". DAŻO, f. 178 , op. 53, spr. 38 , k. 58v-59.

${ }^{56} \mathrm{~W}$ mieście Józefpol. DAŻO, f. 178, op. 53, spr. 36, k. 230.

${ }^{57}$ „Potriebnych swemu stanowi xiążek, nawet Kazusów niema - przez co tak o powinnych stanowi swoiemu zapomniał wiadomości, że na pytania nic nie odpowiedział". DAŻO, f. 178, op. 53, spr. 43, k. 14.

${ }^{58} \mathrm{~Np}$. w parafii Uście, berszadski dekanat, pałamarzem, lub jak określano także w zapisach ponomarzem, był Maksym Kowtunenko „od pańszczyzny wolny, cerkwi usłużny”. DAŻO, f. 178, op. 53, spr. 36, k. 319.

${ }^{59}$ W Narodyczach (owrucki dekanat) był ,szpital o dwóch izbach, ubodzy mieszkaią w nim z Elemozyny, a powinnością ich iest, dzwonic, cerkiew wymiatać z prochów, paięczyn u smiecia oczyszczać, y inne usługi. Ten szpital sumptem WXa Michała Czerwińskiego parocha narodyskiego S Mikołaia Biskupa Mirey cerkwi na koniec, aby ubodzy, bidni, y choruiący przytulisko mieli, a po ulicach nie poniewierali się, wybudowany”. DAŻO, f. 178, op. 53, spr. 43, k. 14.

${ }^{60}$ Tamże. 
metrykalnych. Informacje o księgach metrykalnych przy parafiach pojawiają się już od lat $40-\mathrm{ch}^{61}$. W wizytacyjnych dokumentach $\mathrm{z}$ lat 80 -ch znajdujemy powtarzające się zapisy by kapłan „metrykę porządniej i wyraźniejszym charakterem zapisywał" ${ }^{2}$. Stąd w dekrecie końcowym wizytacji znajdujemy często tego typu notatki: „wielebnemu Xiędzu Watyczowi nakazuję pod karą grzywien 20, aby do niedziel czterech księgę metryki nowej z dwóch liber sporządził, w tą wszystkich chrzczonych przez siebie od początku nastania swego do Łupieni z martwych i szlubnych porządni zapisał" "33. Szczególnie zaś zwracano uwagę na zapisy dzieci miejscowej szlachty: „,metryki dzieci szlacheckich porządnie spisywać y corocznie do grodu powiatowego odsyłać" ${ }^{64}$. Nie przy wszystkich parafiach księgi te istniały, i nie zawsze zależało to od dbałości miejscowego parocha. Świadczą o tym zapisy, że „w czasie najazdów tatarskich y buntów Ukraińskich w wodę są zatopione [księgi]" ${ }^{65}$. $Z$ tego też powodu niektóre parafie utraciły dokumenty funduszowe a duchowni prezenty, upoważniające ich do kierowania daną parafią.

W stosunku do bractw wizytator zalecał dokończenie remontów cerkwi, ogrodzenia cmentarzy, reparacji dzwonnicy, dokupienia niezbędnych ksiąg liturgicznych lub naczyń. Ponieważ delegowani wizytatorzy posiadali władzę by przeprowadzać regulowania granic parafii, zamykania cerkwi ze względu na ich zły stan techniczny, tworzenia nowych parochii, udzielania dyspens, rozgrzeszania, stąd więc w każdym dekanacie napotykamy na przeprowadzone sądy wizytacyjne. Dotyczyły one najczęściej spraw obyczajowych parafian lub zatargów z proboszczem.

Według podobnego schematu są przeprowadzone wizytacje przez Teodora Rostockiego z 1790-1792 r. Materiały wizytacyjne pochodzą z 17 dekanatów: bereźniańskiego, hoszczańskiego, horyńgródskiego, jampolskiego, klewańskiego, koreckiego, krasiłowskiego, łabuńskiego, ostropolskiego, ożochowieckiego, połońskiego, stepańskiego, teofilpolskiego, zasławskiego ${ }^{66}$, przyłuckiego ${ }^{67}$, winnickiego i woronowickiego. Oczywiście zapisy się różnią między sobą, gdyż pomimo istnienia instrukcji wizytacyjnej, każdy $z$ wizytatorów w różny sposób się jej dotrzymywał. W związku z tym, nie można założyć, że potrafimy przeanalizować na jakimś obszarze wiek duchownych czy pochodzenie żon kapłanów, liczbę dzieci gdyż nie wszyscy wizytatorzy to zanotowali.

Znacznie mniej licznie reprezentowane w tych zbiorach są wizyty dziekańskie. Na dzień dzisiejszy odnaleziono pięć poszytów: dziekana bracławskiego ks. J. Laseckiego z 1761-1762 (71 parafii), czeczelnickiego J. Cerkiewicza z 1749

${ }^{61} \mathrm{~W}$ tymże inwentarzu - nr 53 - zachowało się kilkadziesiąt ksiąg metrykalnych parafii greckokatolickich. Najstarsze pochodzą z 1736 r. DAŻO, f. 178, op. 53, spr. 123-198.

${ }^{62} \mathrm{DAŻO}$, f. 178 , op. 53, spr. 38, k. 75 v.

${ }^{63}$ Tamże, k. 71.

${ }^{64}$ DAŻO, f. 178 , op. 53 , spr. 37, k. 180 v.

${ }^{65}$ DAŻO, f. 178, op. 53, spr. 36, k. 319.

${ }^{66}$ Odnalezione przez R. Kondratiuka, zob. charakterystykę protokołów: Р. Ю. Кондратюк, Джерела з історії Уніатської иеркви Південно-Східної Волині другої половини XVIII cm., „Архіви України” nr 4-5 (2001), http://www.archives.gov.ua/Publicat/AU/2001-4-5-5.php

${ }^{67}$ Wydany drukiem: Wizytacje generalne parafii unickich, s. 667-901. 
(58 parafii), jampolskiego ks. Żurakowskiego z 1743-1746 ${ }^{68}$ (26 parafii, urwany tekst), kalnickiego z 1758 (50 parafii) i kaniowskiego ks. B. Andrzejewskiego z 1759 (40 parafii). Ciekawym elementem tych wizytacji są dopiski na brzegach protokołów, związane z oszczędnością papieru, ale też nie zawsze pozwalające na datowanie kolejnych wizyt. Przykładem może tu służyć wizyta dziekańska w Czeczelniku. Pierwszy zapis pochodzi ze stycznia 1749 roku i na tych kartach są dopiski z ustalonych dwóch następnych wizyt czyli lat 1753-1754 oraz 1756. Dotyczyły one najczęściej dokupionych naczyń liturgicznych lub ksiąg.

Wszystkie wizytacje biskupie były przygotowywane w postaci listy parafii w dekanacie, najczęściej na synodzie poprzedzającym wizytacje. W archiwum żytomierskim jednak nie zachowały się żadne tego typu dokumenty. Jest tu natomiast inne, niezwykle ciekawe źródło, odnoszące się już do konsekwencji wizytacji czyli nowe rozgraniczenie dekanatów ${ }^{69}$. Odbyło się ono na synodzie diecezjalnym w czerwcu 1793 roku w Radomyślu, czyli po wizytacji 1790-1792. W celu polepszenia komunikacji pomiędzy dziekanami a podległymi mu duchownymi utworzono kilka nowych dekanatów (jak Bohopol, Buki, Krute, Ładyżyn, Sawrań, Tarnówka) oraz zmniejszono liczbę parafii do 25-34 w każdym dekanacie. Jest to dokument unikatowy, ukazujący nowe rozgraniczenia dekanalne, z zaznaczeniem parafii które przechodzą do innych dekanatów, a także z podaniem nazwisk dziekanów. Można więc prześledzić zmiany granic dekanatów. M.in. nowoutworzony dekanat bucki powstał na bazie 24 parafii sokołowskiego i 7 żywotowskiego ${ }^{70}$. Dekanat jampolski został okrojony do 25 parafii na rzecz nowopowstałego miastkowskiego, włączając w swe granice także parochie jarudzkiego, podzielonego pomiędzy oba dekanaty „,co do referencji XX. Parochów wygodniejszy” "71. Z ,reszty raszkowskiego i józefgródzkiego dekanatu" powstał krutiański ${ }^{72}$. Ze względu na rozlewającą się rzekę Boh ufundowano dekanat sawrański, okrajając józefgródzki, berszadzki, i hołowaniewski, by w ten sposób ułatwić kontakt kapłanom $\mathrm{z}$ dziekanem ${ }^{73}$. Ze względu jednak na kolejne rozbiory postanowienia tego synodu pozostały martwą literą. Po kasacie unii na Ukrainie w latach 1795-1796 oraz 1839 parafie zostały zmuszone na zmiany obrządku.

Wizytacje kanoniczne umożliwiają prześledzenie rozwoju sieci parafialnej a także zmian granic dekanatów ${ }^{74}$, analizy struktury społecznej, wykształcenia duchownych, gęstości zaludnienia i odtworzenie relacji międzywyznaniowych i międzynarodowych.

\footnotetext{
${ }^{68}$ Wizytacja była przeprowadzana częściami: 9 parafii w 1743 r., 12 w 1744, 4 w 1745-1746.

${ }^{69}$ DAŻO, f. 178, op. 53, spr. 71.

${ }^{70}$ Tamże, k. 14.

${ }^{71}$ Tamże, k. 19.

${ }^{72}$ Tamże, k. 20.

${ }^{73}$ Tamże, k. 22.

${ }^{74}$ Zob. I. Водзяновска, Динаміка змін иерковної мережі у кальницькому уніатському деканаті на протязі 1730-1790 років, w: Дні науки Історичного факультету-2011. Матеріали IV Міжнародної наукової конференції молодих учених, присвяченої 20-річчю Незалежності України, вип. IV, ч. 1, Київ 2011, s. 5-6.
} 


\title{
DOCUMENTATION OF THE GREEK CATHOLIC VISITATIONS IN THE STATE ARCHIVE OF ZHYTOMYR OBLAST
}

\begin{abstract}
Summary
In the State Archive of Zhytomyr Oblast there is one of the biggest collections of the visitations of the Greek Catholic parishes in Ukraine. Visitations from the years 1717-1814 territorially include 35 deaneries of eastern territories of the former Polish Republic (now Ukraine, Moldova, Belarus). Scattered in several fonds, the visitation protocols are a record of both canonical visitations and deanery ones. This source enables to characterize socio-religious life of more than 2000 parishes. Those who inspected the parishes noted down not only the name of the parish, to what saints it was dedicated and in which year it was founded, described its appearance and salary but also provided personal details of clergymen and their families. In addition, they presented, in details, the financial security of priests-the fund, mostly in the form of fields, meadows, orchards, fish ponds and various privileges. You can also find information on the density and structure of the population, customs of parishioners, their religious life, their activity, fraternities connected with Uniate churches, schools and hospitals (treated as points of social welfare for the poor and elderly). The visitation material is an interesting source for the research not only on the changes in the deanery structure and the increase in the number of parishes, but also on the relationships between different faiths and peoples inhabiting this land.
\end{abstract}

